\title{
What Is Special About a Humanitarian Logistician? A Survey of Logistic Skills and Performance
}

Gyöngyi Kovács

Humanitarian Logistics and Supply Chain Research Institute (HUMLOG Institute) Hanken School of Economics, Helsinki, Finland kovacs@hanken.fi

Peter Tatham

Department of International Business and Asian Studies, Griffith University Business School, Gold Coast, QLD 4222, Australia p.tatham@griffith.edu.au
Acknowledgments

The authors acknowledge with gratitude the advice and assistance of the Women's Institute for Supply Chain Excellence (WISE) (www.wise.uk.net) in the development of this article, as well as all those individuals who took the time and trouble to respond to our survey questionnaire. We would also like to thank the editor of Supply Chain Forum and the reviewers for their most helpful observations.

The second author would also wish to acknowledge with equal gratitude the support of the HUMLOG Institute at the Hanken School of Economics in the final preparation of this article.

The question of logistics skills is important for management, career development, and education. Existing models of logistics skills have, however, not yet been tested or has their effect on logistics performance been evaluated. This study fills this gap by testing the T-shaped model of logistics skills in the light of logistics performance. Special attention is paid to the respondent group of humanitarian logisticians. The article concludes that the T-shaped model of logistics skills is applicable in both the general as well as the humanitarian logistics setting. The gendered nature of these skills reveals the significance of some male skills that can create an entry barrier to women in logistics.

\section{Introduction}

In the aftermath of a disaster, whether natural or man-made, logistics is a cornerstone of the response of the humanitarian community. Indeed, some commentators have suggested that as much as 80 percent of an NGO's expenditure can be classified under the broad heading of logistics (van Wassenhove, 2006) and, in that sense, a humanitarian organisation is a logistics organisation-albeit one with, typically, a specific mandate and target set of beneficiaries. In parallel, there is evidence that the number and magnitude of the disasters themselves are increasing with a concomitant adverse effect on individuals, communities, and countries (EM-DAT, 2008). The result has been an increasing professionalisation of humanitarian logisticians through an appreciation that training and education can provide tangible improvements to the effectiveness and efficiency of logistics support and, hence, to the recipients of humanitarian aid.

Nevertheless, given that the ultimate aim of humanitarian logistics is to meet the requirements of "end beneficiaries" (Thomas \& Mizushima, 2005), it is clear that the effectiveness of humanitarian logistics depends not only on the outcome of the humanitarian logistics response in terms of moving the required goods and services into the affected area, but also on how successfully the needs of different groups of aid recipients have been ascertained (Kovács \& Tatham, 2009). Indeed, unlike the standard business model, there is a decoupling of financial and material flows with aid workers often acting as proxies for the beneficiaries who are not in a position to articulate their requirements. As a result, it is suggested that although humanitarian and business logisticians may share many common skills and attributes, it is possible that the emphasis placed on each of these varies as a result of the environment in which they are required to operate.

Prior research has looked at logistics skills from a number of perspectives including that of education, that is, which skills and knowledge areas should be emphasised in training programmes and logistics masters 
programmes (Mangan et al., 2001), and from a career development perspective, such as the evaluation of logistics skills needed to advance to senior positions (Murphy \& Poist, 2007). Other authors have investigated the differences between skills required for logisticians versus supply chain managers (Gammelgaard \& Larson, 2001; Dischinger et al., 2006), though in this case the literature has asserted a number of biases that not only reflect the individual author's definition of "logistics," but also that of logisticians themselves, as well as that of hiring organisations (Sohal \& D'Netto, 2004; Trunick, 2007). In this regard, there has been, to date, no agreement on such a definition or on the distinction to be made between logistics and supply chain management. Thus, Larson et al. (2007) discuss four different perspectives on such a differentiation, ranging from a relabelling perspective that equates logistics to supply chain management to intersectional and to different embedded views. Similarly, there is no agreement on the differences between "humanitarian logistics" and the management of "humanitarian supply chains." Which skills humanitarian logisticians need thus depend on their job description and on the view of their particular organisation (i.e., of managers of logisticians) on what logistics entails.

In parallel, there is an equally rich stream of literature that discusses logistics performance that can be broken down into discussions of measures to improve effectiveness and efficiency (Beamon, 1999; Morgan, 2004, 2007). Important, however, is that there appears to be no literature that links the issues of skills needed by a logistician and their effect on logistics performance. The aim of this article is, therefore, twofold: to analyse the skills needed for humanitarian logistics and to evaluate their perceived effect on humanitarian logistics performance. We will elaborate on the research problem and subsequent model construction before reflecting on the methods of the survey and reporting its key findings. The article closes with conclusions and pinpoints some avenues for further research.

\section{Humanitarian logistics skills and performance}

The question of logistics skills is relevant for industry as well as education. In both cases, the skills that are listed are shaped by the definition of logistics in the first place (Sohal \& D'Netto, 2004; Trunick, 2007). Logistics professionals may have several possible affiliations to professional organisations, which may focus on particular areas such as warehousing, transportation, or purchasing, take a supply chain and/or an operations point of view, or be defined by geographical boundaries. Which skills are deemed relevant for logistics thus depends on who gets their say, for example, professionals from warehousing associations would rate warehousing and inventory management-related skills as more important than others (Trunick, 2007). Setting the question of definitions aside, logistics is mainly perceived as an engineering discipline (Sohal \& D'Netto 2004; EP, 2007). The T-shaped skills model for logistics of Mangan and Christopher (2005) is, therefore, one borrowed from engineering (Vereecke et al., 2008; for similar models see Iansiti, 1993, or Weiss, 2005). The main idea behind the concept of T-shaped people is, however, the combination of technical skills (here e.g. forecasting skills) with "softer" managerial knowledge areas (e.g. project management, see Figure 1), both of which are arguably needed in logistics work.

Such a combination is also reflected in the call for humanitarian logistics training (Thomas \& Mizushima, 2005) as well as job descriptions of humanitarian logisticians (CILT, 2008), which include anything from specific customs handling procedures to negotiation skills with warlords. These kinds of specifications in job advertisements give the impression that the set of skills required in humanitarian logistics differs from a commercial setting. Similar to the commercial setting, humanitarianfocused logistics jobs can be of technical-operational nature or be placed among top management. Yet, an analysis of job advertisements in humanitarian logistics points towards two different directions: (1) the emphasis on basic technical skills including maintenance and operations and (2) the requirement of a broader spectrum of management knowledge, especially in the management of interpersonal relationships (Larson, 2009). The general requirement of coordination of activities across humanitarian organisations puts an emphasis on relationship

Figure 1

The T-shaped model of logistics skills (modified from Mangan \& Christopher 2005, p. 60)

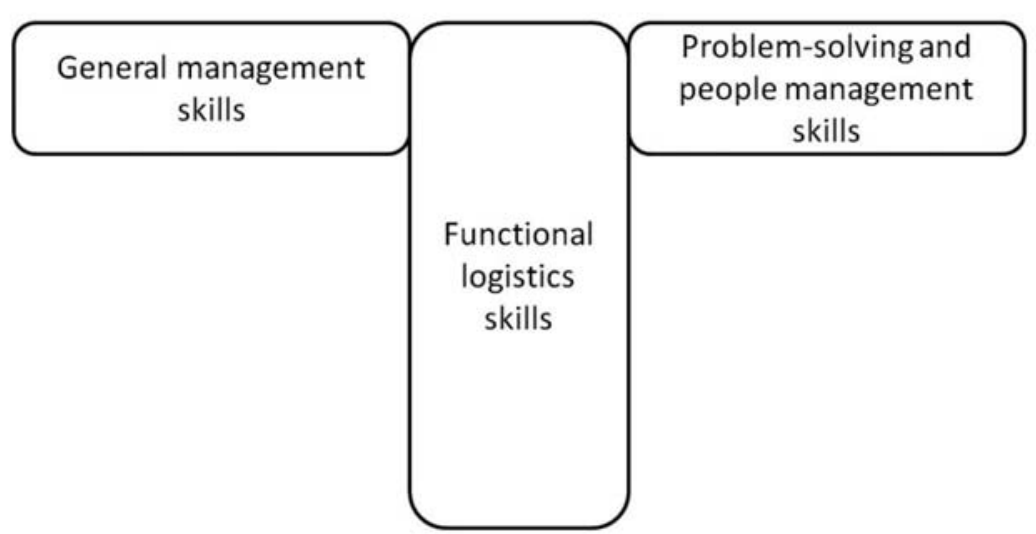


management (van Wassenhove, 2006; Oloruntoba \& Gray, 2006; Kovács \& Spens, 2007). In the case of humanitarian organisations, good relationship management skills are not only needed in the supply chain, but also with competitors.

It is important to note that functional logistics skills and general management skills are not seen as equally important. Indeed, Mangan and Christopher (2005, p.180) suggest that individuals regard themselves as "managers first and logisticians second ... with requisite skills and competencies sets that comprise both general managerial skills and competencies and specific logistics/supply chain skills and competencies", which, indeed, seems to be a consensus view in the literature. Thus, van Hoek et al. (2002) and Vereecke et al. (2008) take a similar line by suggesting that logisticians need to possess not only a core volume of logistics knowledge, but also a set of personal skills. What is more, in line with the differentiation between "market qualifiers" and "market winners" suggested by Mason-Jones et al. (2000), logistics skills are seen as only a qualifier, but not a differentiator (van Hoek et al., 2002). Yet, as the initiative "Skills for Logistics" argues, logistics skills are relevant for the competitive advantage of the industry (Skills for Logistics, 2009). According to this initiative there are still relevant gaps at operational as well as the management levels, which need to be filled through further, more tailored logistics training and education. But although there is also an interest in logistics skills from the perspective of policy makers, interestingly, the suggested T-shaped model has not (yet) been tested in logistics. What is more, despite arguments for differences between humanitarian and commercial settings, there is little understanding as to which skills are relevant to each.

The focus on education and industry relevance leaves yet another question open, namely that of the effect of certain skill sets on logistics performance. This is the more surprising, as it is the effect on logistics performance that renders a skill set relevant in the first place. Logistics performance measurement traditionally focuses on the dimensions of efficiency and effectiveness. As Kovács and Tatham (2009) discuss, breaking down these two results in debates on product and process quality, ontime deliveries, flexibility, time and cost efficiencies, and customer service levels. Beamon and Balcik (2008) suggest a tripartite measurement in terms of (1) resource performance metrics (resource utilisation, quantities, output) such as inventory holding costs to man-hours, (2) output performance metrics (i.e., looking at effectiveness) such as lead times, back-orders and stock-outs, product quantities and qualities, all in accordance with the strategy of an organisation, and (3) flexibility metrics such as shortest delivery lead times and so on. One of the most interesting dimensions related to humanitarian supply chains is that of effectiveness as it is far from unclear whether it is the effectiveness of an organisation, a mission, or aid effectiveness that should be measured. To date, humanitarian logistics literature has focused on organisational (or programme) performance (e.g., de Brito et al., 2007; Schulz \& Heigh, 2007), though disaster management can be scrutinised from the perspective of a disaster region as well. That said, literature on humanitarian logistics performance is limited (Kovács \& Tatham, 2009) and yet performance measurement in humanitarian supply chains is particularly important from the perspective of accountability to beneficiaries as well as donors. The point remains that logistics skills need to have a (positive) effect on logistics performance in order to gain relevance.

Kovács and Tatham (2009) take up another issue of potential importance to humanitarian logistics performance in their discussion of the gender of the humanitarian logistician. There is a parallel ongoing debate in business logistics that relates to distinct career patterns of women logisticians and the contribution of male versus female logisticians to the field. Generally, the underrepresentation of women is criticised in logistics (Lynagh et al., 1999; CSCMP, 2006; Woodward \& Winter, 2006; Trunick, 2007; Vereecke et al., 2008). Related to logistics skills, female logisticians are considered to possess different types of leadership skills (CSCMP, 2006) and better negotiation skills (Min et al., 1995). In the humanitarian setting, there is ample anecdotal evidence of gender affecting logistics performance (Kovács \& Tatham, 2009) due to a (1) gendered access to aid and a differentiated disaster vulnerability among male and female populations (Bradshaw, 2001; Delica, 2002; Enarson, 2002; Fordham, 2002) as well as (2) the lack of female logisticians leading to, for example, gender-insensitive purchasing (ALNAP, 2005).

In summary, the areas of logistics skills, logistics performance, and

\section{Figure 1}

Logistics performance in the light of gender

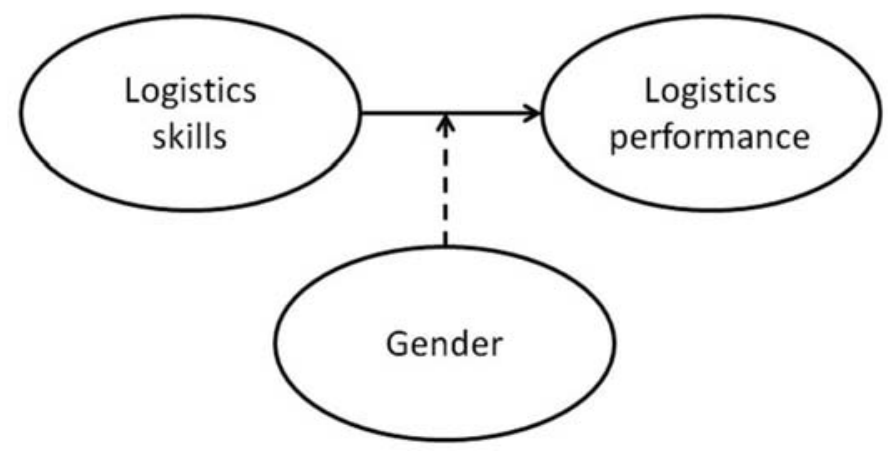


gender are interlinked. Different sets of logistics skills supposedly affect logistics performance, with gender being a mediator between the two. Thus, the following model serves as a basis of our study (see Figure 2):

The sets of skills investigated in the model follow the T-shaped model of logistics skills with its differentiation between functional logistics skills and softer management skills (Mangan \& Christopher, 2005; Vereecke et al., 2008).

\section{Research methods}

The study set out to analyse the skills needed for humanitarian logistics and to evaluate their perceived effect on humanitarian logistics performance. Adhering to T-shaped model of logistics skills and performance, skills are deemed relevant only in light of their effect on logistics performance. This is reflected in the questionnaire used for the study, which asks logisticians and their managers to "indicate the importance, in terms of logistics performance, of [sets of] attributes" on a 7-point Likert scale. The skill sets were directly taken from the T-shaped model of Mangan and Christopher (2005), though refined by other literature on logistics skills (Thomas \& Mizushima, 2005; Murphy \& Poist, 2007; Vereecke et al., 2008). Subsequently, a pilot survey was conducted and administered at the 2008 Logistics Research Network (LRN) conference. The aim of this pilot was to understand if the respondents considered the suggested list of skills and attributes to be complete or whether additions were required. Seventy-five researchers answered the pilot survey, which led to several modifications in the table including adding a number of skills (shown in italics in Table I) and relabelling others. It will be noted that the changes are mostly found in the interpersonal skills area, where, for example, a further distinction was made between people management and human resource management.

In the general management section, a further differentiation was made between customer relationship management and supplier relationship management. In the functional logistics section, areas such as reverse logistics and port management were added on. Table I summarises the resulting skill sets that were then used in the main study.

The model also supposes gender to be a mediating factor and the importance in this regard of the skill set in Table I was also investigated. This was achieved by using the following question that again linked the response to logistics performance: "In terms of logistics performance, please indicate whether you think each of the following functions is best carried out by males or females, or if gender is not important."

The study was carried out as an online survey sent out via various channels to populations of logisticians (humanitarian, business, military) and their managers as well as logistics academics. Mailing lists (such as the LRN list and the Humanitarian Logistics Association [HLA] list) as well as snowball sampling were

Table I

Skills in the T-shaped model

\begin{tabular}{|c|c|c|c|}
\hline General Management Skills & $\begin{array}{l}\text { Functional Logistics } \\
\text { Skills }\end{array}$ & $\begin{array}{l}\text { Problem-Solving } \\
\text { Skills }\end{array}$ & Interpersonal Skills \\
\hline Finance and accounting & Legal & $\begin{array}{l}\text { Problem } \\
\text { identification }\end{array}$ & Listening \\
\hline Information technology & $\begin{array}{l}\text { Customs, import, and } \\
\text { export }\end{array}$ & Information gathering & Oral communication \\
\hline Change management & $\begin{array}{l}\text { Transportation } \\
\text { management }\end{array}$ & Problem analysis & $\begin{array}{l}\text { Written } \\
\text { communication }\end{array}$ \\
\hline Marketing & Inventory management & Information sharing & People management \\
\hline Project management & Warehousing & Problem solving & Meeting facilitation \\
\hline Strategic management & $\begin{array}{l}\text { Purchasing and } \\
\text { procurement }\end{array}$ & & Negotiation \\
\hline $\begin{array}{l}\text { Customer relationship } \\
\text { management }\end{array}$ & Forecasting & & Stress management \\
\hline $\begin{array}{l}\text { Supplier relationship } \\
\text { management }\end{array}$ & Reverse logistics & & $\begin{array}{l}\text { Human resource } \\
\text { management }\end{array}$ \\
\hline Risk management & Port/airport management & & Leadership \\
\hline & $\begin{array}{l}\text { Logistics information } \\
\text { systems }\end{array}$ & & \\
\hline
\end{tabular}


used, and recipients were asked to forward the link to the survey to their colleagues. Response rates can be calculated from the number of site visits (Menachof et al., 2009). The survey site was visited 505 times and resulted in 174 responses, yielding a response rate of 34.5 percent. Among these were seventeen responses from humanitarian logisticians and an additional twelve from their managers; thus, 17.0 percent of responses came from the humanitarian group as a whole (see Figure 3). The further analysis will focus on this humanitarian group in relation to the entire survey population.

The respondents had significant expertise in their field: only 11.5 percent of them had worked fewer than three years in logistics and over 46.6 percent had at least ten years of experience. What is more, respondents came from all around the world. Although the largest population (36.8 percent) was from the U.K. (due to the LRN mailing list), there were respondents from Australia to Uruguay, with the geographical spread being even larger when considering the current deployment location of the respondents. The paucity of women in logistics is often criticised; however, it was interesting to note that 41.4 percent of respondents were female, probably as they felt the survey addressed their situation. Therefore, the respondent population can be considered to have good and global expertise in logistics as well as a genderbalanced insight into questions of gender and logistics skills.

\section{Discussion of findings}

A first analysis of relevant logistics skills shows that problem-solving and interpersonal skills were thought to be more relevant than general management or even functional logistics skills (see Table II). This is somewhat surprising as the survey was, after all, on logistics skills and Mangan and Christopher (2005) specifically pinpoint the importance of general management skills for logisticians. However, the lower general relevance of functional logistics skills can be explained by the suggestion of van Hoek et al. (2002) that these are qualifiers, not differentiators, for a job in logistics. In other words, logisticians need this kind of "textbook knowledge," yet, in order to advance in their careers, they cannot rely on these skills alone.

As for specific skills, only one of them ("marketing") was deemed less relevant (i.e., not significantly

\section{Figure 3 \\ Survey respondent demographics}

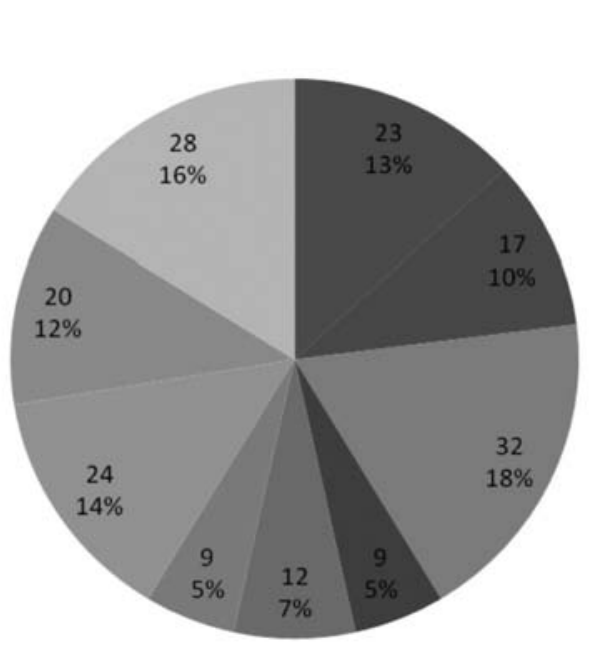

- Business Logistician

- Humanitarian Logistician

- Military Logistician

- Manager of Business Logistician

- Manager of Humanitarian Logistician Manager/Commander of
Military Logistician

= Teacher of Logistics

= Logistics Student

= Other (eg Consultant) relevant), albeit it was not significantly irrelevant, either. All other specific skills were deemed relevant, thereby confirming the $\mathrm{T}$ shaped model of logistics skills from Mangan and Christopher (2005). Thus, the general conclusion is that the T-shaped model of logistics skills is, indeed, applicable to logisticians. More important, all the relevant skills in the model were considered to contribute positively to logistics performance.

"Supplier relationship management" was of specific relevance in the area of general management skills. This can be explained by the management of supplier relations being part of any purchasing process, and thus closely linked to a functional logistics skill. Similarly, "leadership" stood out from the interpersonal skills group, and all problem-solving-related skills were particularly emphasised.

A group split between general (G) and humanitarian $(\mathrm{H})$ cohorts of respondents reveals some interesting differences (see the results of an independent t-test in Table II). Generally, the group split showed that there are significant differences between the skill sets emphasised in humanitarian logistics compared to logistics as a whole. First, differences existed in the general emphasis level of each skill. One possible interpretation is that these skills are, indeed, more relevant to humanitarian logistics and affect logistics performance more. A differing explanation is, however, that respondents from the humanitarian cohort are more polarised in their evaluations than their counterparts from business or military logistics. Specific differences point in the direction of the humanitarian cohort emphasising problem-solving skills even more than their general counterparts. Similarly, there is more emphasis on negotiation skills and, interestingly, purchasing in the humanitarian sector.

Contrary to expectations, differences were not significant when it came to specific skills such as marketing or customs clearance 
Table 2

Relevance of logistics skills

\begin{tabular}{|c|c|c|c|c|c|c|c|c|c|}
\hline \multicolumn{7}{|c|}{ Logistics skill Relevance of logistics skill } & \multicolumn{3}{|c|}{ Gendered nature of the skill } \\
\hline Logistics skill & Group & $\mathrm{N}$ & Mean & Std. Deviation & $t$ & Mean & Std. Deviation & $\begin{array}{l}\text { Std. Error } \\
\text { Mean }\end{array}$ & $T$ \\
\hline \multicolumn{10}{|c|}{ General management skills } \\
\hline $\begin{array}{l}\text { Finance and } \\
\text { accounting }\end{array}$ & $\begin{array}{l}\text { general } \\
\text { humanitari } \\
\text { an }\end{array}$ & $\begin{array}{r}148 \\
26\end{array}$ & $\begin{array}{l}5.03 \\
5.19\end{array}$ & $\begin{array}{l}1.206 \\
1.096\end{array}$ & $-.653^{* *}$ & $\begin{array}{l}3.84 \\
3.88\end{array}$ & $\begin{array}{l}.997 \\
.952\end{array}$ & $\begin{array}{l}.082 \\
.187\end{array}$ & $-.222^{*+}$ \\
\hline Project management & $\begin{array}{l}\text { general } \\
\text { humanitari } \\
\text { an }\end{array}$ & $\begin{array}{r}148 \\
26\end{array}$ & $\begin{array}{l}5.87 \\
5.69\end{array}$ & $\begin{array}{l}1.180 \\
1.258\end{array}$ & $.708^{* *}$ & $\begin{array}{l}4.01 \\
4.04\end{array}$ & $\begin{array}{r}1.027 \\
.871\end{array}$ & $\begin{array}{l}.084 \\
.171\end{array}$ & $-.148^{* *}$ \\
\hline Change management & $\begin{array}{l}\text { general } \\
\text { humanitari } \\
\text { an }\end{array}$ & $\begin{array}{r}148 \\
26\end{array}$ & $\begin{array}{l}5.45 \\
4.88\end{array}$ & $\begin{array}{l}1.406 \\
1.633\end{array}$ & $1.832^{*}$ & $\begin{array}{l}3.91 \\
4.12\end{array}$ & $\begin{array}{r}1.081 \\
.952\end{array}$ & $\begin{array}{l}.089 \\
.187\end{array}$ & $-899^{* *}$ \\
\hline Information technology & $\begin{array}{l}\text { general } \\
\text { humanitari } \\
\text { an }\end{array}$ & $\begin{array}{r}148 \\
26\end{array}$ & $\begin{array}{l}5.61 \\
5.42\end{array}$ & $\begin{array}{l}1.210 \\
1.270\end{array}$ & $.740^{* *}$ & $\begin{array}{l}4.14 \\
4.38\end{array}$ & $\begin{array}{l}.881 \\
.852\end{array}$ & $\begin{array}{l}.072 \\
.167\end{array}$ & $-1.302^{* *}$ \\
\hline Marketing & $\begin{array}{l}\text { general } \\
\text { humanitari } \\
\text { an }\end{array}$ & $\begin{array}{r}148 \\
26\end{array}$ & $\begin{array}{l}4.03 \\
3.23\end{array}$ & $\begin{array}{l}1.433 \\
1.704\end{array}$ & 2.538 & $\begin{array}{l}3.57 \\
3.73\end{array}$ & $\begin{array}{r}.955 \\
1.185\end{array}$ & $\begin{array}{l}.079 \\
.232\end{array}$ & $-.742^{* *}$ \\
\hline Risk management & $\begin{array}{l}\text { general } \\
\text { humanitari } \\
\text { an }\end{array}$ & $\begin{array}{r}148 \\
26\end{array}$ & $\begin{array}{l}5.60 \\
5.69\end{array}$ & $\begin{array}{l}1.233 \\
1.436\end{array}$ & $-.338^{* *}$ & $\begin{array}{l}4.12 \\
3.88\end{array}$ & $\begin{array}{r}.961 \\
1.306\end{array}$ & $\begin{array}{l}.079 \\
.256\end{array}$ & $1.094^{* *}$ \\
\hline Strategic management & $\begin{array}{l}\text { general } \\
\text { humanitari } \\
\text { an }\end{array}$ & $\begin{array}{r}148 \\
26\end{array}$ & $\begin{array}{l}5.62 \\
5.88\end{array}$ & $\begin{array}{l}1.377 \\
1.177\end{array}$ & $-.916^{* *}$ & $\begin{array}{l}4.05 \\
4.15\end{array}$ & $\begin{array}{r}.875 \\
1.008\end{array}$ & $\begin{array}{l}.072 \\
.198\end{array}$ & $-.559^{* *}$ \\
\hline $\begin{array}{l}\text { Customer relationship } \\
\text { management }\end{array}$ & $\begin{array}{l}\text { general } \\
\text { humanitari } \\
\text { an }\end{array}$ & $\begin{array}{r}148 \\
26\end{array}$ & $\begin{array}{l}5.99 \\
5.96\end{array}$ & $\begin{array}{r}1.113 \\
.999\end{array}$ & $.107^{* *}$ & $\begin{array}{l}3.55 \\
3.77\end{array}$ & $\begin{array}{l}1.025 \\
1.336\end{array}$ & $\begin{array}{l}.084 \\
.262\end{array}$ & $-.940^{* *}$ \\
\hline Supplier relationship & general & 148 & 6.13 & 1.114 & $.380^{* *}$ & 3.68 & .990 & .081 & -2.158 \\
\hline & $\begin{array}{l}\text { humanitari } \\
\text { an }\end{array}$ & 26 & 6.04 & 1.113 & & 4.15 & 1.223 & .240 & \\
\hline \multicolumn{10}{|l|}{ Functional logistics skills } \\
\hline Forecasting & $\begin{array}{l}\text { general } \\
\text { humanitari } \\
\text { an }\end{array}$ & $\begin{array}{r}148 \\
26\end{array}$ & $\begin{array}{l}5.89 \\
5.85\end{array}$ & $\begin{array}{l}1.122 \\
1.084\end{array}$ & $.164^{* *}$ & $\begin{array}{l}3.89 \\
4.00\end{array}$ & $\begin{array}{r}.905 \\
1.131\end{array}$ & $\begin{array}{l}.074 \\
.222\end{array}$ & $-.540^{* *}$ \\
\hline Customs/import/export & $\begin{array}{l}\text { general } \\
\text { humanitari } \\
\text { an }\end{array}$ & $\begin{array}{r}148 \\
26\end{array}$ & $\begin{array}{l}5.26 \\
5.85\end{array}$ & $\begin{array}{l}1.351 \\
1.255\end{array}$ & -2.073 & $\begin{array}{l}3.96 \\
4.04\end{array}$ & $\begin{array}{r}.799 \\
1.113\end{array}$ & $\begin{array}{l}.066 \\
.218\end{array}$ & $-.436^{* *}$ \\
\hline Warehousing & $\begin{array}{l}\text { general } \\
\text { humanitari } \\
\text { an }\end{array}$ & $\begin{array}{r}148 \\
26\end{array}$ & $\begin{array}{l}5.57 \\
5.96\end{array}$ & $\begin{array}{l}1.263 \\
1.038\end{array}$ & $-1.503^{* *}$ & $\begin{array}{l}4.24 \\
4.42\end{array}$ & $\begin{array}{l}.923 \\
.809\end{array}$ & $\begin{array}{l}.076 \\
.159\end{array}$ & $-.932^{*+}$ \\
\hline Inventory management & $\begin{array}{l}\text { general } \\
\text { humanitari } \\
\text { an }\end{array}$ & $\begin{array}{r}148 \\
26\end{array}$ & $\begin{array}{l}5.91 \\
5.92\end{array}$ & $\begin{array}{l}1.151 \\
1.197\end{array}$ & $-.072^{* *}$ & $\begin{array}{l}4.04 \\
3.88\end{array}$ & $\begin{array}{l}.824 \\
.952\end{array}$ & $\begin{array}{l}.068 \\
.187\end{array}$ & $-869^{* *}$ \\
\hline $\begin{array}{l}\text { Transportation } \\
\text { management }\end{array}$ & $\begin{array}{l}\text { general } \\
\text { humanitari } \\
\text { an }\end{array}$ & $\begin{array}{r}148 \\
26\end{array}$ & $\begin{array}{l}5.95 \\
6.46\end{array}$ & $\begin{array}{r}1.271 \\
.905\end{array}$ & -1.980 & $\begin{array}{l}4.28 \\
4.42\end{array}$ & $\begin{array}{r}1.055 \\
.902\end{array}$ & $\begin{array}{l}.087 \\
.177\end{array}$ & $-.664^{* *}$ \\
\hline $\begin{array}{l}\text { Purchasing/procureme } \\
\text { nt }\end{array}$ & $\begin{array}{l}\text { general } \\
\text { humanitari } \\
\text { an }\end{array}$ & $\begin{array}{r}148 \\
26\end{array}$ & $\begin{array}{l}5.60 \\
6.00\end{array}$ & $\begin{array}{l}1.216 \\
1.131\end{array}$ & $-1.557^{* *}$ & $\begin{array}{l}3.88 \\
3.96\end{array}$ & $\begin{array}{r}.782 \\
1.038\end{array}$ & $\begin{array}{l}.064 \\
.204\end{array}$ & $-.475^{* *}$ \\
\hline Reverse logistics & $\begin{array}{l}\text { general } \\
\text { humanitari } \\
\text { an }\end{array}$ & $\begin{array}{r}148 \\
26\end{array}$ & $\begin{array}{l}5.43 \\
4.88\end{array}$ & $\begin{array}{l}1.325 \\
1.904\end{array}$ & $1.787^{*}$ & $\begin{array}{l}3.89 \\
4.04\end{array}$ & $\begin{array}{l}.761 \\
.871\end{array}$ & $\begin{array}{l}.063 \\
.171\end{array}$ & $-.927^{* *}$ \\
\hline $\begin{array}{l}\text { Port/airport } \\
\text { management }\end{array}$ & $\begin{array}{l}\text { general } \\
\text { humanitari } \\
\text { an }\end{array}$ & $\begin{array}{r}148 \\
26\end{array}$ & $\begin{array}{l}5.04 \\
5.42\end{array}$ & $\begin{array}{l}1.484 \\
1.528\end{array}$ & $-1.207^{* *}$ & $\begin{array}{l}4.18 \\
4.27\end{array}$ & $\begin{array}{r}.857 \\
1.079\end{array}$ & $\begin{array}{l}.070 \\
.212\end{array}$ & $-.457^{* *}$ \\
\hline Legal specifications & $\begin{array}{l}\text { general } \\
\text { humanitari } \\
\text { an }\end{array}$ & $\begin{array}{r}148 \\
26\end{array}$ & $\begin{array}{l}5.03 \\
5.31\end{array}$ & $\begin{array}{l}1.382 \\
1.320\end{array}$ & $-.938^{* *}$ & $\begin{array}{l}3.91 \\
3.92\end{array}$ & $\begin{array}{l}.750 \\
.891\end{array}$ & $\begin{array}{l}.062 \\
.175\end{array}$ & $-108^{*+4}$ \\
\hline Logistics information & general & 148 & 5.99 & 1.113 & $1.242^{* *}$ & 4.04 & .790 & .065 & -2.024 \\
\hline
\end{tabular}


(i.e., p-values were below 0.05). There was also less difference in the importance of stress management as a skill, even though one would expect humanitarian logisticians to work under significant stress. However, the significant difference in the importance of negotiation skills (with a higher emphasis in the humanitarian cohort) fit well with CILT's (2008) analysis of humanitarian job descriptions stressing negotiation skills. Other specific differences (see, for example, the evaluation of "transportation management") turned out not to be significant.

Looking at gender as a mediating factor, the overall question of "Do you think the gender of the logistician affects logistics performance?" was evaluated as having a very low effect with means of 2.36 (general) and 3.00 (humanitarian) on the 7-point Likert scale. Although the difference between cohorts is significant, the overall finding is that gender has no significant effect on logistics performance. This is rather surprising, as the literature suggests that there is ample anecdotal evidence for the gender of the logistician affecting the performance of an operation (Kovács \& Tatham, 2009) but may of course have come up as we had more female respondents than employment data in logistics would suggest. What is more, respondents provided seventy-nine stories in which the gender of the logistician affected positively (40) or negatively (39) on logistics performance. Thus there is a discrepancy between the strictly statistical significance of the question and the anecdotal evidence provided by the same respondents. Table III summarises the stories given by the humanitarian logisticians in the survey. The tenor of these comments is that both male and female logisticians are needed, and that gender should not matterthough it may.

A closer analysis of the gendered nature of logistics skills reveals that the following skills are deemed predominantly "female": a number of general management skills such as "finance and accounting," "marketing," and "customer relationship management"; the functional logistics skill of "legal specifications"; problem-solving skills such as "information gathering" and "information sharing"; and interpersonal skills such as "listening" and "oral" as well as "written communication."

Table 3

Gender and logistics

\begin{tabular}{|c|c|}
\hline \multirow{12}{*}{ 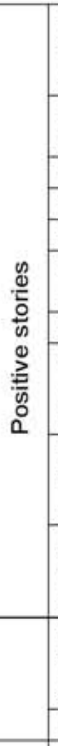 } & $\begin{array}{l}\text { Presence of female logistician had a positive impact in terms of better information sharing, improved coordination and record keeping. We recently } \\
\text { hired a female warehouse manager in Myanmar operation who was able to manage the transit warehouse with fewer resources and ensured better } \\
\text { coordination within the team. }\end{array}$ \\
\hline & $\begin{array}{l}\text { Admin skills and customer orientation are usually better developed with women on the other hand technical skills seem to be better developed with } \\
\text { men. }\end{array}$ \\
\hline & Women are more political and cultural sensitive. \\
\hline & Far less corruption problem (again according to context/country) so generally better on supply and procurement. \\
\hline & When dealing with female beneficiaries. \\
\hline & $\begin{array}{l}\text { It has been the "male" logistician who had to deal with all the logisticians in branches. There were situations that he had to face and solve that would be } \\
\text { more difficult for a female logistician. }\end{array}$ \\
\hline & Females seem to be especially good at managing information systems. \\
\hline & $\begin{array}{l}\text { In most developing countries men are involved in logistics and often having a woman manager/supervisor creates additional challenges (I say this as a } \\
\text { woman manager, though not in logistics). The impact is not because men or women are better at logistics but because of the cultures we have to work } \\
\text { in. }\end{array}$ \\
\hline & $\begin{array}{l}\text { In needs identification given that most of those who are normally affected are women so it is easier for women to access women, understand and } \\
\text { interpret their actual needs. Women are also quality focused and know a lot more on domestic needs than technical like choosing generators or } \\
\text { vehicles. }\end{array}$ \\
\hline & $\begin{array}{l}\text { Although humanitarian organizations are striving to increase the number of female logisticians, in most of the areas where we operate women are } \\
\text { underrespected or simply banned of performing certain activities. In this context performing logistics activities that require direct interaction with men is } \\
\text { challenging, time consuming and most of the time frustrating for women. In Uganda for example, having both women and men working as logisticians }\end{array}$ \\
\hline & $\begin{array}{l}\text { has shown that men could perform some tasks such as negotiating procurement of goods or managing staff more easily than women. Having said that } \\
\text { it is also true that this ease in interacting with the host community is not related to the capacity or skills of women, but with gender discrimination } \\
\text { embedded in the society. }\end{array}$ \\
\hline & There are countries where both male and female have positive impacts in logistics management. \\
\hline \multirow{8}{*}{ 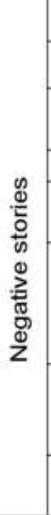 } & Incomplete admin leading to donor non compliance \\
\hline & Her position in the field may be undermined \\
\hline & $\begin{array}{l}\text { Mostly due to cultural context. In some context it is not wise/possible to have a women to deal with authority or supplier (more generally external } \\
\text { negotiation or relation) }\end{array}$ \\
\hline & In times of conflict. \\
\hline & $\begin{array}{l}\text { 1. Females being put in a position not because they are suitable but because they are females.ie gender policy of the organisation. } 2 \text {. Field hardship } \\
\text { posts requiring stamina. }\end{array}$ \\
\hline & $\begin{array}{l}\text { In a case of managing delicate intimate needs of women, for example hygiene products which should include sanitary towels. Unless a man is a doctor } \\
\text {, nurse or say has medical background then most of them shy off she it comes to dealing with such needs, besides they would not think of them but } \\
\text { rather think of vehicles, generators shelter etc not the gender impact of their decision. This we continue to see, recently in Tsunami, Pakistani } \\
\text { earthquake etc }\end{array}$ \\
\hline & $\begin{array}{l}\text { In Sierra Leone, when having community meetings with right holders for a logistics assessment, female logisticians sometimes faced harassment and } \\
\text { strong opposition from the stakeholders. This fact in turn delayed the completion of the task in hand and created resistance and lack of collaboration } \\
\text { during community assessments. }\end{array}$ \\
\hline & $\begin{array}{l}\text { However, negative impact for female logisticians is in countries where there are serious security concerns and in some place has cultural issues. } \\
\text { Otherwise, gender is not an issue. }\end{array}$ \\
\hline
\end{tabular}


Interestingly, "negotiation skills" were not seen as "female," thus not confirming the earlier findings of Min et al. (1995). Overall, comparing the "rather female" skills to the general importance of these skills shows that these are generally deemed less relevant for logistics performance. A relevant and gendered, though rather "male," skill is that of leadership. Two of the functional logistics skills ("transportation" and "warehousing") were also deemed "male." Considering the market qualifier nature of functional logistics skills, the perception of these skills being male has farreaching consequences for women in logistics in general, as the male perception of these skills can represent an entry barrier for females into the logistics profession.

Last but not least, a group split between the general and the humanitarian cohort reveals that the humanitarian respondents as a group tended to evaluate each of the skills as more male than their business or military logistician counterparts. Generally, thus, it is not surprising that humanitarian logistics is seen as such a male field. Looking at the representation of females in the general work force, the humanitarian cohort reports a balanced to femaledominated overall organisation, but the mean of female humanitarian logisticians is 20 percent.

Few exceptions to the more male perception of skills are represented by "risk management," "inventory management," "problem identification," and "oral communication," which humanitarians perceive as more female than the general cohort.

\section{Conclusions and further research}

A first, overall conclusion of the study is the confirmation of the Tshaped model of logistics skills, both in the general as well as the specific humanitarian sector. More important, it is concluded that all these groups of skills have an effect on logistics performance. It is interesting, however, that the market-qualifier group of skills, that is, functional logistics skills, is generally deemed less relevant for logistics performance than the market-winning skills of problem solving and interpersonal skills. However, market qualifiers are the basis of the profession (van Hoek et al., 2002) and thus cannot be neglected in their significance for logistics performance. This is a particularly important point when looking at the gendered nature of these skills, two of them being perceived "rather male." Their male perception may create an entry barrier for females wanting to enter the logistics field.

The gender analysis led to surprising findings. The overall conclusion was that gender should not matter for logistics, yet a large number of anecdotes were provided by the same respondents quoting situations in which the gender of the logistician was, in fact, of importance. In light of this discrepancy between statistical significance and the anecdotes, the question of gender in logistics deserves more attention in further research.

Generally, however, "female" skills were less relevant, whereas "male" skills were highly relevant for the profession and for logistics performance. Thus, although gender does not matter in most of the skills, the few male skills that stand out carry significant importance for the logistics profession.

There are a number of avenues for further research that should be pursued. First, based on the survey, a further analysis could be done of the other cohorts (business, military, and academic ones). Second, it would be valuable to investigate a case in which the skills of a number of groups of logisticians were investigated in relation to the performance outcomes of a particular operation. Finally, we call for more research in the specific field of humanitarian logistics and humanitarian logisticians. Understanding the similarities and differences between the different application areas of logistics will help managers to find the right person for their job, and educators to further develop programmes that emphasise the skills needed in these professions.

\section{References}

ALNAP. (2005). South Asia earthquake 2005: Learning from previous earthquake relief operations. Available from w w w. od i . or g. u k/A L N A P / publications/pdfs/ALNAP ProVention_SAsia_Quake_Lessonsa.pdf (accessed 10 July 2007).

Beamon, B. M. (1999). Measuring supply chain performance. International Journal of Operations and Production Management, 19(3), 275-292.

Beamon, B. M., \& Balcik, B. (2008). Performance measurement in humanitarian relief chains. International Journal of Public Sector Management, 21(1), 4-25.

Bradshaw, S. (2001). Reconstructing roles and relations: Women's participation in reconstruction in postMitch Nicaragua. Gender and Development, 9(3), 79-87.

CILT. (2008). Humanitarian \& emergency logistics personnel: Logisticians job description assessment. Available from www.ciltuk.org.uk/download/helpanaly sis.pdf (accessed 25 February 2009).

CSCMP. (2006). 2006 career patterns of women in logistics. Available from http://cscmp.org/

Downloads/Public/Career/06CareerPatt ernsWomen.pdf (accessed 27 July 2007).

de Brito, M., van der Laan, E., \& Vergunst, D. (2007). Humanitarian organisations and performance measurement. In P. Tatham (Ed.), CDROM proceedings of the International Humanitarian Logistics Symposium. Faringdon, UK.

Delica, Z. G. (2002). Enhancing women's capacity to manage and recover from disasters (Chapter 1). Working paper 7. $\mathrm{ILO}$ in-focus programme on crisis response and reconstruction, crises, women and other gender concerns, 1-3. Available from www.ilo. 
org/public/english/employment/crisis/d ownload/wp7.pdf (accessed 10 July 2007).

Dischinger, J., Closs, D. J., McCulloch, E., Speier, C., Grenoble, W., \& Marshal, L. D. (2006). The emerging supply chain management profession. Supply Chain Management Review, 10(1), 62-68.

EM-DAT. (2008). Emergency events database Université Catholique de Louvain. Available from www.emdat.be/ Database/terms.html (accessed 29 January 2009).

Enarson, E. (2002). Gender issues in natural disasters: Talking points on research needs (Chapter 2). Working paper 7. ILO in-focus programme on crisis response and reconstruction, crises, women and other gender concerns, 5-12. Available from www.ilo.org/public/ english/employment/crisis/download/w p7.pdf (accessed 10 July 2007).

EP (European Parliament). (2007). Women and transport (provisional version). Available from IP/B/TRAN/ST/ 2005-008 (accessed 26 June 2006).

Fordham, M. (2002). The place of gender in earthquake vulnerability and mitigation. Available from www.iiasa.ac. at/Research/RMS/july2000/Papers/ford ham0208.pdf (accessed 9 July 2007).

Gammelgaard, B., \& Larson P. (2001). Logistics skills and competencies for supply chain management. Journal of Business Logistics, 22(2), 27-50.

Iansiti, M. (1993). Real-world R\&D: Jumping the product generation gap. Harvard Business Review, 71(3), 138-147.

Kovács, G., \& Spens, K. M. (2007) Humanitarian logistics in disaster relief operations. International Journal of Physical Distribution and Logistics Management, 37(2), 99-114.

Kovács, G., \& Tatham, P. H. (2009) Humanitarian performance in the light of gender. International Journal of Productivity and Performance Management, 58(2), 174-187.

Larson, P. D. (2009). Angels in humanitarian logistics. Keynote speech at the 2nd CCHLI Symposium. Faringdon, UK.
Larson, P. D., Poist, R. F., \& Halldórsson, Á. (2007). Perspectives on logistics vs supply chain management: A survey of SCM professionals. Journal of Business Logistics, 28(1), 1-24.

Lynagh, P. M., Murphy, P. R., \& Poist, R. F. (1999). Career perspectives of women in distribution: Congruency or contrast? International Journal of Physical Distribution \& Logistics Management, 29(9), 192-206.

Mangan, J., \& Christopher, M. (2005). Management development and the supply chain manager of the future. International Journal of Logistics Management, 16(2), 178-191.

Mangan, J., Gregory, O., \& Lalwani, C. (2001). Education, training and the role of logistics managers in Ireland. International Journal of Logistics. Research and Applications, 4(3), 313-327.

Mason-Jones, R., Naylor, B., \& Towill, D. R. (2000). Lean, agile or leagile? Matching your supply chain to your marketplace. International Journal of Production Research, 38(17), 4061-4070.

Menachof, D. A., Gibson, B. J., Hanna, J. B., \& Whiteing, A. E. (2009). An analysis of the value of supply chain management periodicals. International Journal of Physical Distribution and Logistics Management, 39(2), 145-166.

Min, H., LaTour, M. S., \& Jones, M. A. (1995). Negotiation outcomes: The impact of the initial offer, time, gender, and team size. The Journal of Supply Chain Management, 31(4), 9-24.

Morgan, C. (2004). Structure, speed and salience: Performance measurement in the supply chain. Business Process Management Journal, 10(5), 522-536.

Morgan, C. (2007). Supply network performance measurement: Future challenges? International Journal of Logistics Management, 18(2), 255-273.

Murphy, P., \& Poist, R. (2007). Skill requirements of senior-level logisticians: A longitudinal research assessment. Supply Chain Management: An International Journal, 12(6), 423-431.

Oloruntoba, R., \& Gray, R. (2006) Humanitarian aid: An agile supply chain? Supply Chain Management: An International Journal, 11(2), 115-120
Schulz, S., \& Heigh, I. (2007). Logistics performance management in action. Proceedings of the First International Humanitarian Logistic Symposium. Faringdon, UK.

Skills for Logistics. (2009). Skills for logistics: About us. Available from http://www.skillsforlogistics.org/en/ind ex/aboutus/ (accessed 31 May 2009).

Sohal, A. S., \& D'Netto, B. (2004). Incumbent perceptions of the logistics profession. International Journal of Logistics Systems and Management, 1(1) $5-25$

Thomas, A., \& Mizushima, M. (2005). Logistics training: Necessity or luxury? Forced Migration Review, 22, 60-61.

Trunick, P. A. (2007). Women in logistics Logistics Today, 48(12), 24-25.

van Hoek, R., Chatham, R., \& Wilding, R. (2002). Managers in supply chain management: The critical dimension. Supply Chain Management: An International Journal, 7(3), 119-125.

van Wassenhove, L. N. (2006). Humanitarian aid logistics: Supply chain management in high gear. Journal of the Operational Research Society, 57(5), 475589.

Vereecke, A., Boute, R., van Dierdonck, R., \& Seernels, S. (2008, November). Supply chain managers-Who needs them? Insights from a European survey on the profile and the role of the supply chain manager. White paper. Vlerick Leuven Gent Management School.

Weiss, A. (2005). Conquering complexity: Lessons for defence systems acquisition. London: The Stationery Office.

Woodward, R. \& Winter, P. (2006). Gender and the limits to diversity in the contemporary British army, Gender, Work \& Organization, 13(1), 45-67. 


\section{About the Authors}

Gyöngyi Kovács is an acting professor in supply chain management and corporate geography at the Hanken School of Economics in Helsinki, Finland, where she also earned her PhD. She is director of the Humanitarian Logistics and Supply Chain Research Institute (HUMLOG Institute). Apart from humanitarian logistics, her research interests include sustainable supply chain management, supply chain collaboration, the abductive research approach, and reverse logistics. She has published in the

Peter Tatham joined the Royal Navy in 1970 and served in a variety of appointments during his career of some thirty-five years. Highlights include logistics officer of the Aircraft Carrier HMS INVINCIBLE in 1994/1995 during operations in Bosnia against the former Republic of Yugoslavia and chief staff officer responsible for all high level personnel and logistics issues emanating from the ten thousand sailors and thirty surface ships in the Royal Navy (1999-2000). His final three years in the Service were spent in the Defence Logistics Organisation where he was responsible for key elements of the internal programme of change management (2000-2004). During this period, he also gained an MSc in defence logistic management. Following his retirement from the Royal Navy, he joined the staff of Cranfield University at Shrivenham in the UK, where he lectured on defence and humanitarian logistics and human systems. He earned his PhD from Cranfield University researching the extent of trust within military supply networks. He has recently joined the faculty of Griffith University Business School on the Gold Coast of Queensland, Australia, as a senior lecturer in the fields of supply network management and humanitarian logistics. Recently been appointed as the Australian Editor of the Journal of Humanitarian Logistics and Supply Chain Management, he has also published in the Journal of Business Logistics, the International Journal of Production Engineering and in the International Journal of Physical Distribution and Logistics Management. 